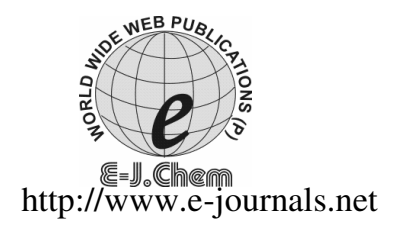

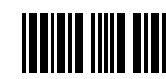

ISSN: 0973-4945; CODEN ECJHAO

E-Journal of Chemistry

2011, 8(1), 53-58

\title{
Groundwater Quality of Open Wells and Tube Wells around Amalner Town of Jalgaon District, Maharashtra, India
}

\author{
V.T. PATIL ${ }^{*}$ and P.R. PATIL \\ *Department of Chemistry, Z.B.Patil College, Dhule 424 002, Maharashtra, India \\ School of Environmental and Earth Sciences, North Maharashtra University \\ Jalgaon-425 001, Maharashtra, India \\ vijaypatil14@rediffmail.com
}

Received 8 February 2010; Accepted 20 April 2010

\begin{abstract}
Groundwater samples (Three open wells, three tube wells) were collected from six different locations around Amalner town and analyzed during November 2007-February 2008. Fifteen physicochemical parameters were analyzed and the results were compared with water quality standards prescribed by WHO and ISI 10500-91. In the present study, two water samples (one open well, one tube well) showed high EC, TDS, TA, TH values indicating poor water quality. The correlation coefficients were calculated. The significance of the results is further discussed.
\end{abstract}

Keywords: Groundwater, Physicochemical parameters, Correlation analysis.

\section{Introduction}

Water is a vital source of life which is extremely essential for survival of all living organisms. Life is not possible on this planet without water. About $97.2 \%$ of water on earth is salty and only $2.8 \%$ is present as fresh water from which about $20 \%$ constitutes groundwater ${ }^{1}$. Groundwater serves as a major source for drinking, irrigation and industry. Groundwater is generally considered to be much cleaner than surface water. However, several factors such as discharge of industrial, agricultural and domestic wastes, land use practices, geological formation, rainfall patterns and infiltration rate affects the groundwater quality and once contamination of groundwater in aquifers occurs, it persists for hundreds of years because of very slow movement in the ${ }^{2}$. Water gets polluted due to contamination by foreign matter such as microorganism, chemicals, industrial or other wastes or sewage. These matters deteriorate the quality of the water and render it unfit for its intended uses. Water pollution is the introduction into fresh or ocean waters of chemical, physical or biological material that degrades the water quality and affects the organisms living in $\mathrm{it}^{3}$. Ingestion of polluted water can result various health problems. Disposal of sewage water into 
fresh water aquifers is the main cause of groundwater pollution. Hence determination of groundwater quality is important to observe the suitability of water for particular use. Groundwater monitoring of open wells and tube wells is one of the important tool for evaluating groundwater quality. Considering these aspects of groundwater pollution the present study of groundwater monitoring was undertaken to investigate physicochemical characteristics of some groundwater samples around Amalner town.

\section{Experimental}

\section{Study area}

Amalner town (latitude $21^{0} 2^{\prime} 30^{\prime}$ ' $\mathrm{N}$ and longitude $75^{\circ} 4^{\prime} \mathrm{E}$ ) in Jalgaon District lies at Northern region of Maharashtra state with an expected population of about 1 lakh by the end of $10^{\text {th }}$ five year plan. The present study was planned by selecting six different sites around Amalner area which included three sites from villages Mangrul, Nandgaon and Dhar. The literature survey showed that no groundwater studies were made in these regions so far. Hence the present study was undertaken.

\section{Collection of water samples}

The groundwater samples were collected in plastic canes of three litre capacity as per standard procedure. Water samples from six sampling points situated at different places were collected during a post monsoon period of four months (November 2007 to February 2008). The samples were kept in refrigerator maintained at $4{ }^{\circ} \mathrm{C}$. The sampling points are given in Table 1.

Table 1. Sampling points

\begin{tabular}{clll}
\hline S. No. & \multicolumn{2}{c}{ Sampling points } & Source \\
\hline 1 & Galwade area & $\left(\mathbf{S}_{\mathbf{1}}\right)$ & Open well \\
2 & Mangrul & $\left(\mathbf{S}_{\mathbf{2}}\right)$ & Open well \\
3 & Deoli Road & $\left(\mathbf{S}_{\mathbf{3}}\right)$ & Open well \\
4 & Railway Crossing & $\left(\mathbf{S}_{\mathbf{4}}\right)$ & Tube well \\
5 & Nandgaon & $\left(\mathbf{S}_{\mathbf{5}}\right)$ & Tube well \\
6 & Dhar & $\left(\mathbf{S}_{\mathbf{6}}\right)$ & Tube well \\
\hline
\end{tabular}

\section{Analysis of water samples}

The physicochemical parameters such as $\mathrm{pH}$, electrical conductivity (EC), total dissolved solids (TDS), turbidity (Turb), dissolved oxygen (DO), total alkalinity (TA), total hardness (TH), calcium $\left(\mathrm{Ca}^{2+}\right)$ magnesium $\left(\mathrm{Mg}^{2+}\right)$, sodium $\left(\mathrm{Na}^{+}\right)$, potassium $\left(\mathrm{K}^{+}\right)$, chloride $\left(\mathrm{Cl}^{-}\right)$, nitrate $\left(\mathrm{NO}_{3}{ }^{-}\right)$, sulphate $\left(\mathrm{SO}_{4}{ }^{2-}\right)$ and phosphate $\left(\mathrm{PO}_{4}{ }^{3-}\right)$ were determined using standard methods $^{4-6}$. AR grade reagents were used for the analysis and double distilled water was used for preparation of solutions. The methods used for estimation of various physicochemical parameters are tabulated in Table 2.

Table 2. Methods used for estimation of physicochemical parameters

\begin{tabular}{lll}
\hline S.No. & Parameters & Method \\
\hline 1 & pH & pH Metry \\
2 & Electrical Conductivity & Conductometry \\
3 & Total Dissolved Solids & Filtration method \\
4 & Turbidity & Nephelometric method \\
5 & Dissolved Oxygen & Iodometric method \\
6 & Total alkalinity & Titration method \\
\hline
\end{tabular}




\begin{tabular}{lll}
\hline 7 & Total hardness & EDTA titration \\
8 & Calcium & EDTA titration \\
9 & Magnesium & EDTA titration \\
10. & Sodium & Flame Photometric method \\
11. & Potassium & Flame Photometric method \\
12. & Chloride & Silver Nitrate method \\
13. & Sulphate & Turbidimetric method \\
14. & Nitrate & Brucine method \\
15. & Phosphate & Stannous Chloride method \\
\hline
\end{tabular}

A simple linear correlation analysis has been carried out to find out correlation between any two tested parameters. The significance of correlation was studied.

\section{Results and Discussion}

The average results of the physicochemical parameters for water samples are presented in Table 3.

Table 3. Average results of the physicochemical parameters

\begin{tabular}{|c|c|c|c|c|c|c|c|c|}
\hline \multirow{2}{*}{ S.No. } & \multirow{2}{*}{ Parameter } & \multicolumn{6}{|c|}{ Sampling points } & \multirow{2}{*}{ ISI 10500-91 } \\
\hline & & $S_{1}$ & $\mathbf{S}_{2}$ & $\mathbf{S}_{\mathbf{3}}$ & $\mathbf{S}_{4}$ & $\mathbf{S}_{5}$ & $S_{6}$ & \\
\hline 1 & $\mathrm{pH}$ & 7.5 & 7.3 & 7.7 & 7.3 & 7.1 & 7.5 & $6.5-8.5$ \\
\hline 2 & $\mathrm{EC}$ & 813.5 & 1516 & 491.8 & 591.6 & 1846 & 997.1 & $1400^{*}$ \\
\hline 3 & TDS & 320 & 680 & 400 & 360 & 1280 & 480 & 500 \\
\hline 4 & Turbidity & 0.4 & 0.2 & 0.1 & 0.1 & 3.1 & 1.7 & 5.0 \\
\hline 5 & DO & 7.0 & 7.6 & 5.6 & 2.0 & 4.0 & 4.0 & $5.0 *$ \\
\hline 6 & TA & 272 & 200.9 & 227.7 & 263.4 & 300 & 292 & 200 \\
\hline 7 & $\mathrm{TH}$ & 386 & 714 & 274 & 282 & 716 & 456 & 300 \\
\hline 8 & $\mathrm{Ca}^{2+}$ & 80.16 & 141.9 & 58.52 & 60.12 & 152.3 & 100.2 & 75 \\
\hline 9 & $\mathrm{Mg}^{2+}$ & 45.32 & 87.71 & 31.19 & 32.16 & 81.87 & 50.19 & 30 \\
\hline 10 & $\mathrm{Na}^{+}$ & 77.09 & 78.98 & 46.07 & 59.23 & 195.6 & 81.79 & $200 *$ \\
\hline 11 & $\mathrm{~K}^{+}$ & 0.603 & 0.402 & 0.603 & 0.804 & 2.011 & 0.603 & --- \\
\hline 12 & $\mathrm{Cl}^{-}$ & 74.66 & 222.6 & 21.13 & 43.67 & 333.8 & 100.01 & 250 \\
\hline 13 & $\mathrm{NO}_{3}^{-}$ & 0.451 & 1.202 & 0.437 & 0.178 & 0.901 & 0.669 & 45 \\
\hline 14 & $\mathrm{SO}_{4}{ }^{2-}$ & 29.21 & 61.79 & 21.35 & 15.73 & 40.45 & 50.56 & 200 \\
\hline 15 & $\mathrm{PO}_{4}{ }^{3-}$ & 0.078 & 0.233 & 0.155 & 0.078 & 0.233 & 0.155 & ---- \\
\hline
\end{tabular}

$\mathrm{pH}$ is a measure of the intensity of acidity or alkalinity and the concentration of hydrogen ion in water. $\mathrm{pH}$ value below 4 produces sour taste and a higher value above 8.5 give alkaline taste ${ }^{5}$. In the present study, the $\mathrm{pH}$ values of water samples varied between 7.1 to 7.7 (Table 3) and were found within the limit prescribed by ISI 10500-91.

\section{Electrical conductivity (EC)}

Electrical conductivity is a measure of water capacity to convey electric current. It signifies the amount of total dissolved salts ${ }^{7}$. EC values were observed in the range of 491.8 micromhos/cm to 1846 micromhos/cm. EC values were found within WHO limit except sampling sites $\mathbf{S}_{\mathbf{2}}$ (Open well) and $\mathbf{S}_{\mathbf{5}}$ (Tube well) indicating the presence of high amount of dissolved inorganic substances in ionized form. 


\section{Total dissolved solids (TDS)}

High concentrations of total dissolved solids may cause adverse taste effects. TDS values varied from $320 \mathrm{mg} / \mathrm{L}$ to $1280 \mathrm{mg} / \mathrm{L}$. The sampling points $\mathbf{S}_{\mathbf{2}}$ and $\mathbf{S}_{\mathbf{5}}$ showed higher TDS values than the prescribed limit given by ISI 10500-91.

\section{Turbidity}

Turbidity makes water unfit for domestic purposes, food and beverage industries and many other industrial uses. In the present analysis, turbidity values varied between 0.1 to $3.1 \mathrm{NTU}$ and found within the limits prescribed by WHO and ISI 10500-91.

\section{Dissolved oxygen (DO)}

Dissolved oxygen reflects the physical and biological processes prevailing in the water. The DO values indicate the degree of pollution in water bodies. In the present analysis of water samples, DO value varied from 2.0 to 7.6. The sampling points $\mathbf{S}_{\mathbf{4}}, \mathbf{S}_{\mathbf{5}}$ and $\mathbf{S}_{\mathbf{6}}$ showed low DO values indicating heavy contamination by organic matter.

\section{Alkalinity}

Alkalinity is a total measure of substance in water that has "acid-neutralizing" ability. The main sources of natural alkalinity are rocks which contain carbonate, bicarbonate and hydroxide compounds; borates, silicates and phosphates may also contribute to alkalinity ${ }^{3}$. Total alkalinity values for all the investigated samples were found to be greater than the value prescribed by ISI 10500-91.

\section{Total hardness $(\mathrm{TH})$}

Hardness in water is due to the natural accumulation of salts from contact with soil and geological formations or it may enter from direct pollution by industrial effluents. Hardness of water mainly depends upon the amount of calcium or magnesium salts or both ${ }^{8}$. In the present study, total hardness varied from $274 \mathrm{mg} / \mathrm{L}$ to $716 \mathrm{mg} / \mathrm{L}$. The values for open well sample from point $\mathbf{S}_{\mathbf{1}}, \mathbf{S}_{\mathbf{2}}$ and tube well sample from point $\mathbf{S}_{\mathbf{5}}, \mathbf{S}_{\mathbf{6}}$ were higher than the prescribed limit.

\section{Calcium and magnesium $\left(\mathrm{Ca}^{2+}, \mathrm{Mg}^{2+}\right)$}

Water with high calcium content is undesirable for household uses such as washing, bathing and laundering because of consumption of more soap and other cleaning agents. In the present investigation, calcium concentration ranged from $58.52 \mathrm{mg} / \mathrm{L}$ to $152.3 \mathrm{mg} / \mathrm{L}$ and found higher than prescribed ISI 10500-91 limits except open well sample $\left(\mathbf{S}_{\mathbf{3}}\right)$ and tube well sample $\left(\mathbf{S}_{\mathbf{4}}\right)$.

At high concentrations, magnesium salts have a laxative effect particularly when present as magnesium sulphate. Magnesium content in the investigated water samples was varied from $31.19 \mathrm{mg} / \mathrm{L}$ to $87.71 \mathrm{mg} / \mathrm{L}$ and found above perscribed limit.

\section{Sodium $\left(\mathrm{Na}^{+}\right)$}

Excessive amount of sodium in drinking water is harmful to persons suffering from cardiac, renal and circulatory diseases. Sodium concentrations in the present analysis were found from $46.07 \mathrm{mg} / \mathrm{L}$ to $195.6 \mathrm{mg} / \mathrm{L}$ and were within the prescribed limit.

\section{Potassium $\left(\mathrm{K}^{+}\right)$}

Potassium is an essential nutrition element but in excessive amounts, it act as cathartic. Potassium content in the water samples varied from $0.402 \mathrm{mg} / \mathrm{L}$ to $2.011 \mathrm{mg} / \mathrm{L}$.

\section{Chloride $\left(\mathrm{Cl}^{-}\right)$}

The most important source of chlorides in the waters is the discharge of domestic sewage. People accustomed to higher chloride in water are subjected to laxative effects ${ }^{7}$. In the present analysis, chloride concentration was found in the range of $21.13 \mathrm{mg} / \mathrm{L}$ to $333.8 \mathrm{mg} / \mathrm{L}$. The values are within the limit except water sample collected from point $\mathbf{S}_{\mathbf{5}}$. 
Higher chloride concentration in sample from point $\mathbf{S}_{\mathbf{5}}$ may be due to discharge of sewage near the sampling site.

Nitrate $\left(\mathrm{NO}_{3}^{-}\right)$

Groundwater can also be contaminated by sewage and other wastes rich in nitrates. In excessive amounts, nitrate may cause methemoglobinemia in infants, a disease characterized by blood changes ${ }^{6}$. The nitrate content in the study area varied in the range $0.178 \mathrm{mg} / \mathrm{L}$ to $1.202 \mathrm{mg} / \mathrm{L}$ and found within the prescribed limit.

\section{Sulphate $\left(\mathrm{SO}_{4}^{2-}\right)$}

Discharge of industrial wastes and domestic sewage tends to increase sulphate concentration. Sulphate as magnesium sulphate causes laxative effects. In the present analysis, sulphate concentration varied between $15.73 \mathrm{mg} / \mathrm{L}$ and $61.79 \mathrm{mg} / \mathrm{L}$ and found within the prescribed limit.

Phosphate $\left(\mathrm{PO}_{4}{ }^{3-}\right)$

Phosphate occurs in groundwater as a result of domestic sewage, detergents, agricultural effluents with fertilizers and industrial waste water. The phosphate content in the study was found in the range of $0.078 \mathrm{mg} / \mathrm{L}$ to $0.233 \mathrm{mg} / \mathrm{L}$.

\section{Statistical analysis}

Correlation is the mutual relationship between two variables. Direct correlation exists when increase or decrease in the value of one parameter is associated with a corresponding increase or decrease in the value of other parameter ${ }^{9}$. The correlation coefficients (r) among various quality parameters were calculated and the values are given in Table 4.

Table 4. Correlation matrix for different water quality parameters

\begin{tabular}{|c|c|c|c|c|c|c|c|c|}
\hline Parameter & $\mathrm{pH}$ & $\mathrm{EC}$ & TDS & Turb. & DO & TA & $\mathrm{TH}$ & $\mathrm{Ca}^{2+}$ \\
\hline $\mathrm{pH}$ & 1 & & & & & & & \\
\hline $\mathrm{EC}$ & -0.777 & 1 & & & & & & \\
\hline TDS & -0.757 & 0.899 & 1 & & & & & \\
\hline Turb & -0.561 & 0.707 & 0.828 & 1 & & & & \\
\hline DO & 0.281 & 0.184 & -0.081 & -0.303 & 1 & & & \\
\hline TA & -0.292 & 0.158 & 0.301 & 0.736 & -0.575 & 1 & & \\
\hline $\mathrm{TH}$ & -0.704 & $0.980^{*}$ & 0.815 & 0.577 & 0.323 & -0.009 & 1 & \\
\hline $\mathrm{Ca}^{2+}$ & -0.714 & $0.991^{*}$ & 0.848 & 0.650 & 0.262 & 0.075 & $0.995^{*}$ & 1 \\
\hline $\mathrm{Mg}^{2+}$ & -0.687 & $0.961^{*}$ & 0.774 & 0.498 & 0.380 & -0.093 & $0.995^{*}$ & $0.982^{*}$ \\
\hline $\mathrm{Na}^{+}$ & -0.761 & 0.844 & $0.942^{*}$ & $0.913 *$ & -0.152 & 0.563 & 0.723 & 0.771 \\
\hline $\mathrm{K}^{+}$ & -0.684 & 0.600 & 0.854 & 0.841 & -0.417 & 0.620 & 0.436 & 0.494 \\
\hline $\mathrm{Cl}^{-}$ & -0.811 & $0.989^{*}$ & $0.946^{*}$ & 0.732 & 0.117 & 0.185 & $0.949^{*}$ & $0.963^{*}$ \\
\hline $\mathrm{NO}_{3}^{-}$ & -0.429 & 0.852 & 0.635 & 0.369 & 0.532 & -0.272 & $0.932^{*}$ & $0.912^{*}$ \\
\hline $\mathrm{SO}_{4}^{2-}$ & -0.296 & 0.716 & 0.407 & 0.319 & 0.464 & -0.164 & 0.813 & 0.801 \\
\hline $\mathrm{PO}_{4}^{3-}$ & -0.429 & 0.819 & 0.790 & 0.511 & 0.277 & -0.202 & 0.851 & 0.852 \\
\hline Parameter & $\mathrm{Mg}^{2+}$ & $\mathrm{Na}^{+}$ & $\mathrm{K}^{+}$ & $\mathrm{Cl}^{-}$ & $\mathrm{NO}_{3}^{-}$ & $\mathrm{SO}_{4}^{2-}$ & $\mathrm{PO}_{4}^{3-}$ & \\
\hline $\mathrm{Mg}^{2+}$ & 1 & & & & & & & \\
\hline $\mathrm{Na}^{+}$ & 0.669 & 1 & & & & & & \\
\hline $\mathrm{K}^{+}$ & 0.375 & $0.918^{*}$ & 1 & & & & & \\
\hline $\mathrm{Cl}^{-}$ & $0.928^{*}$ & 0.889 & 0.694 & 1 & & & & \\
\hline $\mathrm{NO}_{3}^{-}$ & $0.944^{*}$ & 0.474 & 0.149 & 0.795 & 1 & & & \\
\hline $\mathrm{SO}_{4}^{2-}$ & 0.817 & 0.299 & -0.071 & 0.613 & $0.913 *$ & 1 & & \\
\hline $\mathrm{PO}_{4}^{3-}$ & 0.843 & 0.578 & 0.383 & 0.810 & 0.898 & 0.724 & 1 & \\
\hline
\end{tabular}


EC showed highly significant positive correlation with TDS, TH, $\mathrm{Ca}^{2+} \mathrm{Mg}^{2+}, \mathrm{Cl}^{-}, \mathrm{NO}_{3}^{-}$ and $\mathrm{PO}_{4}{ }^{3-}$.TDS showed highly significant positive correlation with Turb, $\mathrm{TH}, \mathrm{Ca}^{2+} \mathrm{Na}^{+}, \mathrm{K}^{+}$ and $\mathrm{Cl}^{-}$. This suggests that electrical conductivity depends on dissolved solids which depend on salts ${ }^{10}$ such as $\mathrm{NaCl}, \mathrm{CaCl}_{2}$. Total hardness showed significant correlation with $\mathrm{Ca}^{2+}$ $\mathrm{Mg}^{2+}, \mathrm{Cl}^{-}, \mathrm{NO}_{3}^{-}, \mathrm{SO}_{4}{ }^{2-}$ and $\mathrm{PO}_{4}{ }^{3-}$. So it may be suggested that total hardness of the experimental water samples may be due to presence of salts of these ions.

Some weak correlation is observed between $\mathrm{TA}$ and $\mathrm{Ca}^{2+}(\mathrm{r}=0.075)$ so that alkalinity is weakly depend on $\mathrm{Ca}^{2+}$. $\mathrm{pH}$ showed negative correlation with most of the parameters.

\section{Conclusion}

In the current study, the groundwater samples showed deviations from water quality standards indicating groundwater contamination. The open well sample from point $\mathbf{S}_{\mathbf{2}}$ and tube well water sample from point $\mathbf{S}_{\mathbf{5}}$ showed high EC,TDS, TA,TH than the prescribed limits given by water quality standards indicating poor water quality and water from these sites is unfit for drinking purpose. The open well water samples from point $\mathbf{S}_{\mathbf{1}}, \mathbf{S}_{3}$ and tube well water samples from point $\mathbf{S}_{\mathbf{4}}, \mathbf{S}_{\mathbf{6}}$ showed most of the parameters within the limits of water quality standards showing good water quality and the water from these sampling points is fit for drinking purpose.

\section{Acknowledgement}

The authors are thankful to UGC under Minor research project for providing financial support.

\section{References}

1. Jameel A and Sirajudeen J, Environ.Monit.Assess. 2006,123, 299.

2. Jayalakshmi Devi $\mathrm{O}$ and Belagali $\mathrm{S}$ L, Nature, Environment and pollution Technology.2006, 5(4), 553.

3. Garg D, Kaur R, Chand D, Mehla S and Singh R, Rasayan J Chem., 2008, 1(4), 743.

4. American Public Health Association: Standard Methods for the examination of water and waste water, $17^{\text {th }}$ Ed., Washington, DC. 1989.

5. Trivedy R K and Goel P K Chemical and Biological methods for water pollution studies Environmental Publication, Karad, 1986.

6. Manivaskam N, Physicochemical examination of water sewage and industrial effluent. 5th ed. Pragati Prakashan Meerut, 2005.

7. Sudhir Dahiya and Amarjeet Kaur, J Environ Pollut., 1999, 6(4), 281.

8. Shrinivasa Rao B and Venkateswarlu P, Indian J Environ Prot., 2000, 20(3), 161.

9. Karunakaran K, Thamilarasu P and Sharmila R, E-J Chem. 2009, 6(3), 909.

10. Shah M C, Shilpkar P, and Sharma S, Asian J Chem. 2007, 19(5), 3449. 


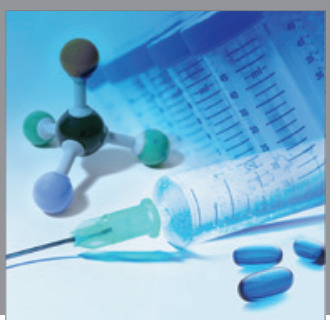

International Journal of

Medicinal Chemistry

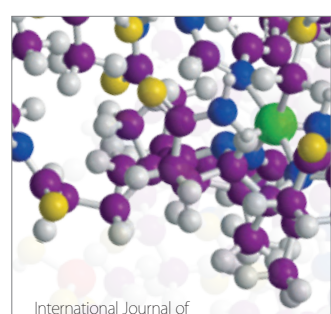

Carbohydrate Chemistry

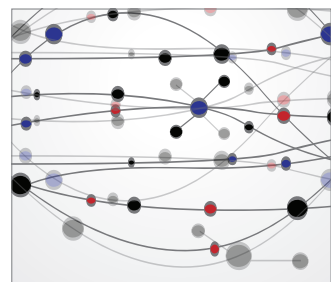

The Scientific World Journal
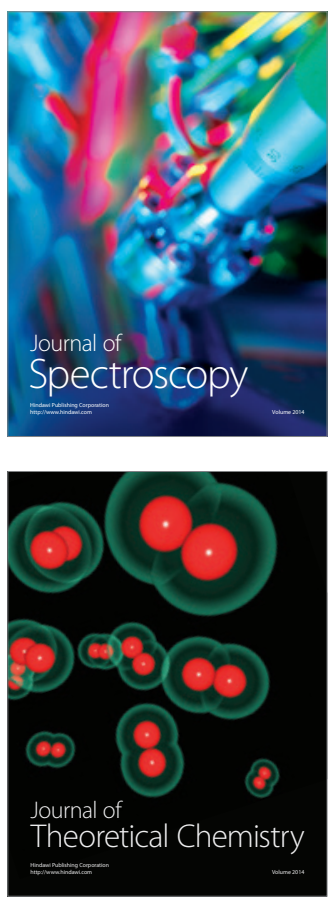
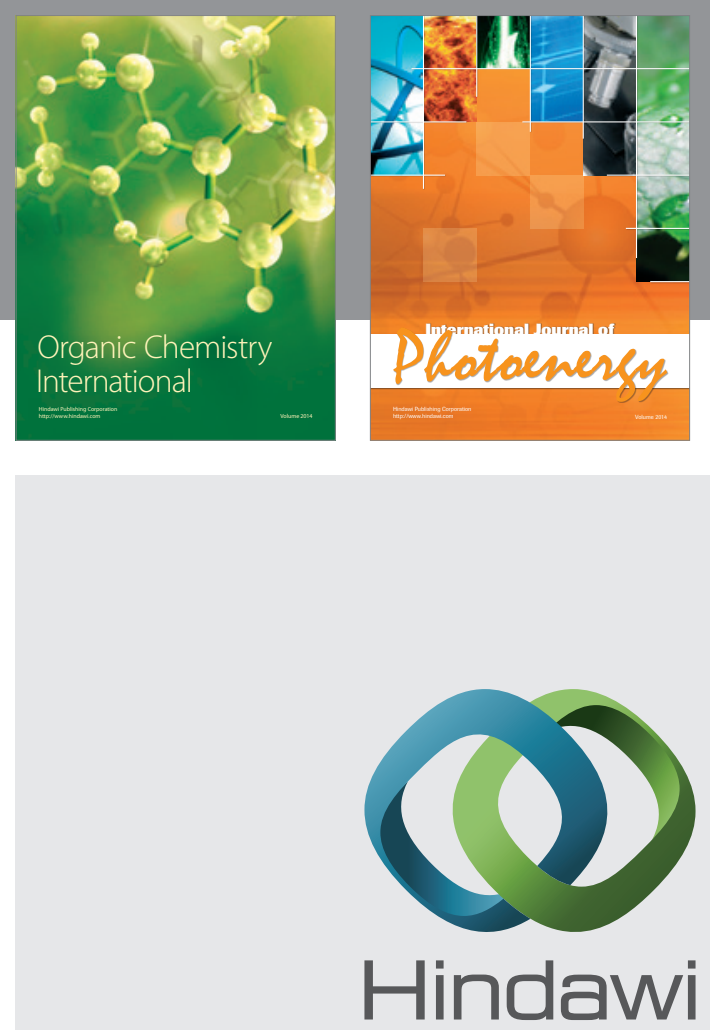

Submit your manuscripts at

http://www.hindawi.com
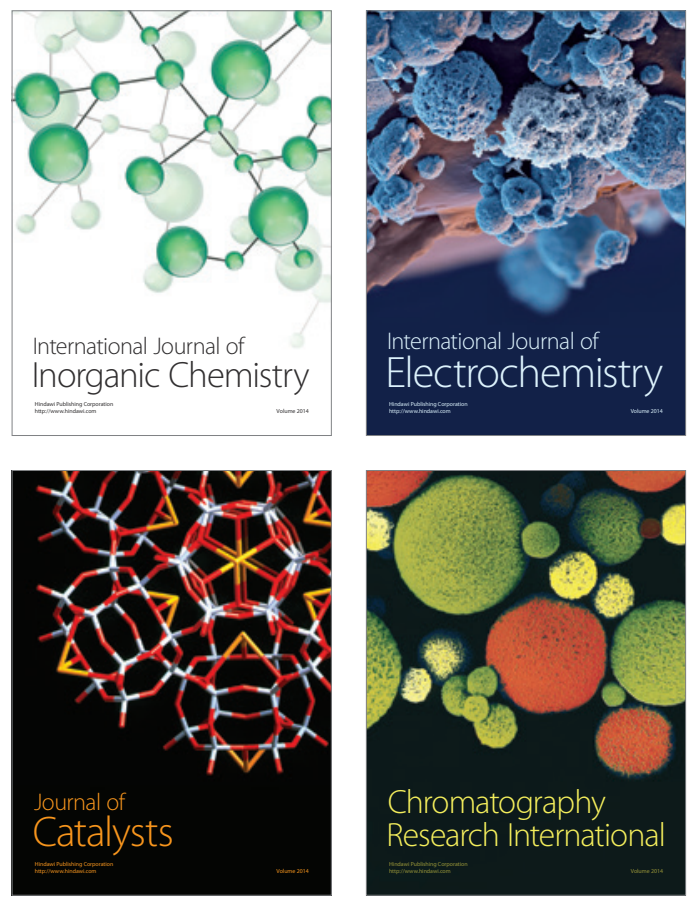
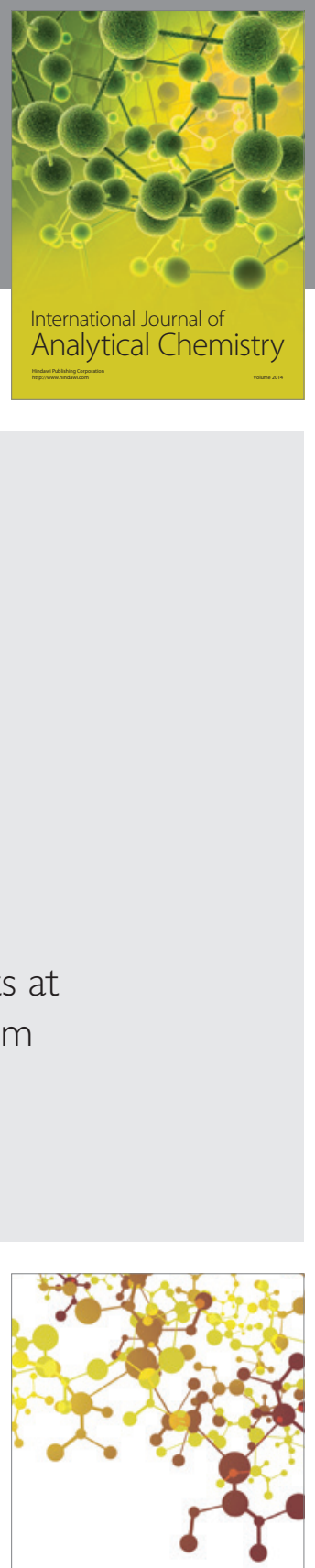

Journal of

Applied Chemistry
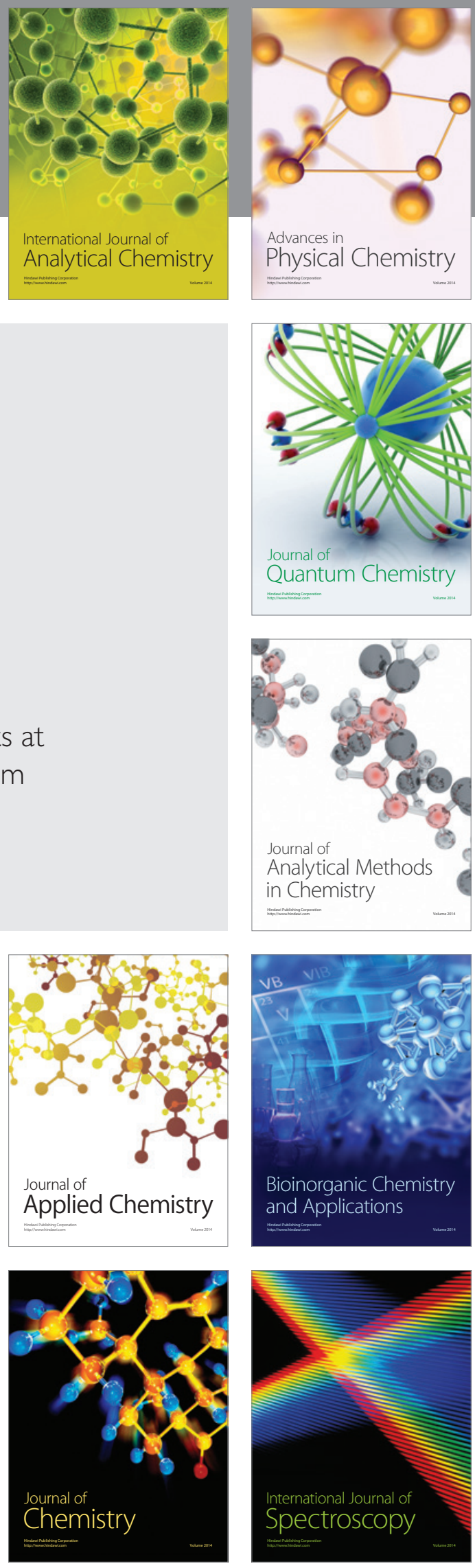